\title{
Dentition Variations in the Common Polecat in Poland
}

\author{
Andrzej L. RUPRECHT
}

Ruprecht A. L., 1978: Dentition variations in the common polecat in Poland. Acta theriol., 23, 12: 239-245 [With 2 Tables \& 1 Fig.].

Examination was made of the range of tooth pattern variations in a large number of skulls of Mustela putorius L in na e us, 1758 from Poland $(n=801)$. Additional upper incisors and upper incisors with fused crowns were found to occur more frequently in males $(2.9 \%)$ than in females $(1.8 \%)$, whereas the percentage of additional $M^{2}$ did not differ in individuals of the two sexes. The greater skull dimensions of common po'ecats from the Rzeszów population were accompanied by a more variable tooth pattern. Comparison of the number of teeth in polecats from Poland and Holland revealed a more strongly marked tendency to oligodonty in the latter $(P<0.001)$.

[Mammals Res. Inst., Polish Acad. Sci., 17-230 Białowieża, Poland]

\section{INTRODUCTION}

There is a considerable amount of literature on dentition variation in Mustelidae, the greater part of which consists of descriptions of single cases defined as anomalies (Reinwaldt, 1958; Fullag a r et al., 1960; G eld e r \& McLaughlin, 1961; M a zák, 1964;

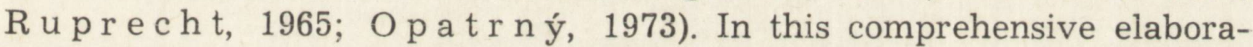
tion of variations in number of teeth in Carnivora $\mathrm{Hall}$ (1940) drew attention to the fact that deviations in the number of teeth occur more often in certain species, while in others this happens either very rarely or not at all. The greater interest taken in cases of differences in the tooth pattern of mammals of the Mustelidae family has permitted of defining more exactly the nature of certain of its variants and to connect it with the effect of various forms of conditioning ( $\mathrm{R} \mathrm{öt} \mathrm{ch}$ e r, 1965; H e p tn e r, 1968; B a t e m a n, 1970, H e r á ň, 1971; N e u e ns chwander \& L üps, 1975; Glas, 1977).

\section{MATERIAL AND METHODS}

The material used consisted of skulls of $M$. putorius $(n=801)$ collected in Polish territory from 1959-1970 and obtained from the Mammals Research Institute, Polish Academy of Sciences at Białowieża; the author's own collection; Institute of Systematics and Experimental Zoology, PAS in Kraków; Zoological Institute of the B. Bierut University in Wroclaw and Institute of Zoology, PAS 
Table 1

Deviation in tooth pattern of the common polecat in Poland from sex and population aspect.

Populations: 1 - West Pomeranian Lake District, 2-Białowieża Primeval Forest, 3-West part of Central Poland Lowlands, 4-East part of Central Poland Lowlands, 5-Małopolska Upland, 6-Rzeszów environs, 7 - other regions.

\begin{tabular}{|c|c|c|c|c|c|c|c|c|c|c|c|c|c|c|c|c|c|c|}
\hline \multirow{3}{*}{$\begin{array}{l}\text { Population } \\
\text { No. of specimens }\end{array}$} & \multicolumn{9}{|c|}{ Males $(n=482)$} & \multicolumn{9}{|c|}{ Females $(n=319)$} \\
\hline & \multirow{2}{*}{$\begin{array}{r}1 \\
75\end{array}$} & \multirow{2}{*}{$\begin{array}{r}2 \\
84\end{array}$} & \multirow{2}{*}{$\begin{array}{r}3 \\
26\end{array}$} & \multirow{2}{*}{$\begin{array}{r}4 \\
32\end{array}$} & \multirow{2}{*}{$\begin{array}{r}5 \\
21\end{array}$} & \multirow{2}{*}{$\begin{array}{r}6 \\
207\end{array}$} & \multirow{2}{*}{$\begin{array}{r}7 \\
37\end{array}$} & \multicolumn{2}{|c|}{ Total } & \multirow{2}{*}{$\begin{array}{r}1 \\
52\end{array}$} & \multirow{2}{*}{$\begin{array}{r}2 \\
45\end{array}$} & \multirow{2}{*}{$\begin{array}{r}3 \\
25\end{array}$} & \multirow{2}{*}{22} & \multirow{2}{*}{$\begin{array}{r}5 \\
16\end{array}$} & \multirow{2}{*}{$\begin{array}{r}6 \\
134\end{array}$} & \multirow{2}{*}{$\begin{array}{r}7 \\
25\end{array}$} & \multicolumn{2}{|c|}{ Total } \\
\hline & & & & & & & & $\mathrm{n}$ & $\%$ & & & & & & & & $\mathrm{n}$ & $\%$ \\
\hline \multicolumn{19}{|c|}{ Supernumerary teeth } \\
\hline$I^{1}$ & 3 & 0 & 1 & 0 & 0 & 7 & 0 & 11 & 2.3 & 0 & 0 & 1 & 0 & 0 & 2 & 0 & 3 & 0.9 \\
\hline$I_{3}$ & 0 & 1 & 0 & 0 & 0 & 0 & 0 & 1 & 0.2 & 0 & 0 & 0 & 0 & 0 & 0 & 0 & 0 & \\
\hline$P_{3}$ & 1 & 0 & 0 & 0 & 0 & 0 & 0 & 1 & 0.2 & 0 & 0 & 0 & 0 & 0 & 0 & 0 & 0 & \\
\hline$M^{2}$ & 0 & 0 & 0 & 0 & 0 & 1 & 0 & 1 & 0.2 & 0 & 0 & 1 & 1 & 0 & 0 & 0 & 2 & 0.6 \\
\hline \multicolumn{19}{|l|}{ Missing teeth } \\
\hline$I_{2}$ & 0 & 0 & 0 & 0 & 0 & 0 & 0 & 0 & & 0 & 1 & 0 & 0 & 0 & 0 & 0 & 1 & 0.3 \\
\hline$P^{1}$ & 2 & 1 & 1 & 1 & 1 & 2 & 0 & 8 & 1.6 & 0 & 0 & 0 & 0 & 1 & 2 & 1 & 4 & 1.2 \\
\hline$P_{1}$ & 3 & 1 & 1 & 0 & 1 & 1 & 0 & 7 & 1.4 & 1 & 1 & 0 & 0 & 1 & 0 & 0 & 3 & 0.9 \\
\hline$C_{1}$ & 0 & 0 & 0 & 1 & 0 & 0 & 0 & 1 & 0.2 & 1 & 0 & 0 & 0 & 0 & 0 & 0 & 1 & 1.3 \\
\hline$M^{1}$ & 0 & 0 & 0 & 0 & 0 & 0 & 0 & 0 & & 1 & 0 & 0 & 0 & 0 & 0 & 0 & 1 & 0.3 \\
\hline$M_{2}$ & 0 & 1 & 0 & 1 & 0 & 2 & 0 & 4 & 0.8 & 1 & 0 & 0 & 0 & 0 & 0 & 1 & 2 & 0.6 \\
\hline \multicolumn{19}{|l|}{ Fused teeth } \\
\hline$I^{1+2}$ & 1 & 0 & 1 & 0 & 0 & 1 & 0 & 3 & 0.6 & 0 & 0 & 1 & 0 & 0 & 2 & 0 & 3 & 0.9 \\
\hline$P^{1}$ with 2 roots & 1 & 0 & 0 & 0 & 0 & 0 & 0 & 1 & 0.2 & 0 & 0 & 0 & 0 & 0 & 0 & 0 & 0 & \\
\hline$P^{2}$ with 3 roots & 0 & 1 & 0 & 0 & 0 & 0 & 0 & 1 & 0.2 & 0 & 0 & 0 & 0 & 0 & 0 & 0 & 0 & \\
\hline$P_{3}$ with 3 roots & 0 & 1 & 1 & 0 & 0 & 0 & 0 & 2 & 0.4 & 0 & 0 & 0 & 0 & 0 & 0 & 0 & 0 & \\
\hline
\end{tabular}


in Warsaw. The material was divided into 7 regional groups ( $\mathrm{Buchalczyk}$ \& Ruprecht, 1977): (1) West Pomeranian Lake District; (2) Białowieża Primeval Forest, (3) west part of Central Poland Lowlands; (4) east part of Central Poland Lowlands; (5) Małopolska Upland; (6) Rzeszów region; (7) other regions, analyzing the differences found by means of the chi-square test. Analogical numeration of regional groups, together with the number of skulls in these samples, is given in Table 1. The number of teeth in Polish and Dutch populations of $M$. putorius were compared by means of the $t$-Student test for mean independent groups (Table 2).

\section{RESULTS}

Examination of differences in frequency of tooth pattern variants in M. putorius within: (1) sex, (2) population and (3) age groups showed that:

(1) None of the deviations in number of teeth analyzed in the whole of the material depend significantly on $\operatorname{sex}\left(\chi^{2}=1.4224 ; 0.2<P<0.3\right)$;

(2) Frequencies of deviations in number of teeth in the Rzeszów and Białowieża populations did not differ significantly $\left(\chi^{2}=0.3956\right.$; $0.5<P<0.7)$;

(3) Frequencies of different kinds of polydonty in different age groups do not differ significantly $\left(\chi^{2}=0.7488 ; 0.75<P<0.5\right)$, while oligodonty increases with age to a degree which is very highly significant statistically $\left(\chi^{2}=54.5400 ; P<0.005\right)$.

Comparison of tooth patterns in the common polecat from Poland and Holland revealed a very strongly marked tendency to oligodonty in the latter $(P<0.001)$.

\section{Table 2}

Variations in number of teeth in the common polecat in Poland $(n=801)$ and Holland ( $\mathrm{n}=385$; after G la s, 1977).

\begin{tabular}{|c|c|c|c|c|c|c|c|c|c|c|c|}
\hline Number of teeth & 28 & 29 & 30 & 31 & 32 & 33 & 34 & 35 & 36 & $\overline{\mathrm{x}} \pm \mathrm{SD}$ & C.v. \\
\hline & \multicolumn{9}{|c|}{ Poland ( $\mathrm{M}$ and $\mathrm{F}$ ) } & $33.9 \pm 0.02$ & 0.55 \\
\hline Males $\left.(n=482)^{1}\right)$ & 0 & 0 & 0 & 1 & 2 & 15 & 451 & 10 & 3 & & \\
\hline \multirow[t]{2}{*}{ Females $\left.(n=319)^{2}\right)$} & 0 & 0 & 0 & 1 & 2 & 7 & 304 & 4 & 1 & & \\
\hline & \multicolumn{9}{|c|}{ Netherlands (M } & $31.7 \pm 0.04$ & 1.10 \\
\hline Males $(n=206)$ & 0 & 1 & 12 & 15 & 173 & 4 & 1 & 0 & 0 & & \\
\hline Females $\left.(n=179)^{8}\right)$ & 1 & 3 & 16 & 20 & 138 & 1 & 0 & 0 & 0 & & \\
\hline
\end{tabular}

1 No. coll. $29260 \mathrm{M}$ had both a missing $P^{1}$ and $M_{2}$; No. coll. $31249 \mathrm{M}$ had both a supernumerary $I^{1}$ and missing $P_{1}$ teeth; No. coll. $386468 \mathrm{M}$ had both a missing $P^{1}$ and $M_{2}$ teeth.

3) No. coll. $393 \mathrm{~F}$ had both a missing $P_{1}$ and $M_{2}$ teeth.

3) No. coll. absent $\mathrm{F}$ had both a supernumerary incisor and missing molar. 


\section{DISCUSSION}

Polydontism of upper incisors is a variant of tooth pattern commonly occurring in $M$. putorius ( $R$ e inwald t, 1958; Röt tcher, 1965; B a t e man, 1970; Glas, 1977). Additional lower incisors $I_{3}$ in the common polecat from Poland, however, occurred very rarely, like additional $\mathrm{I}_{2}$, found in the stone marten from Czechoslovakia (O p a$\operatorname{trny}, 1973$ ). As in the case of the wolf (Dolgov \& Rossoímo, 1964), in the common polecat also additional upper incisors occurred more often in males. This points to the genetic conditioning, connected with sex, of this character. Additional $M^{2}$ - a rare manifestation of atavistic polydontism in $M$. putorius - occurred in similar percentages in both sexes in material from Poland. The genesis of additional $M^{2}$ in $M$. putorius is explained in the same way by $\mathrm{Glas}$ (1977), who

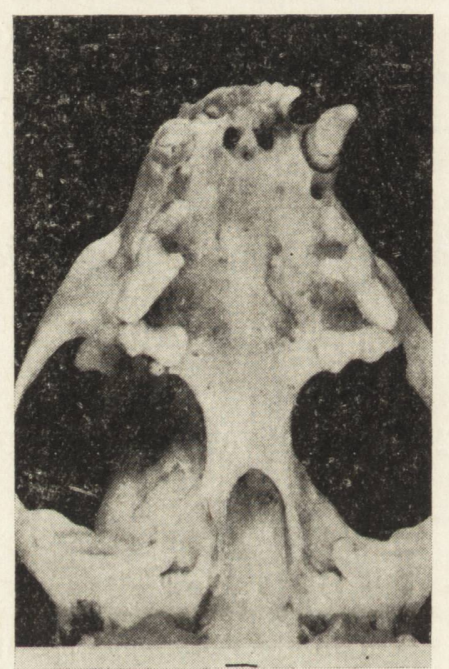

Fig. 1. Additional $M^{2}$ dex in a female of $M$. putorius in four age class (coll. no. $\mathrm{M} / 3830 / 68$ ) from Niemodlin district. Photo S. Buszko.

found these teeth to occur in three cases only in a group of 385 skulls of the common polecat from Holland. These teeth are particularly rarely encountered in the badger ( $\mathrm{Fullagar}$ et al., 1960), whereas in $M$. nivalis from Hesse they occurred in as many as $6.4 \%$ of the individuals examined ( $N$ e u e $\mathrm{nschw}$ ander \& L üps, 1975). The last example referred to would appear to point indirectly to the considerable stability of the number of molars in $M$. putorius in Poland. Additional molars seem to occur more frequently in Canidae than in other carnivores, and in them are always situated at the end of the 
tooth row (H a ll, 1940; Dolgov \& Rossolimo, 1964). A distinction must be made between cases of atavistic polydonty of molars in Mustelidae and all other differences in the situation and structure of these teeth (M a zák, 1964; N e uens chwander \& L üps, 1975). Polydonty of $P_{3}$ is a very rare variant of the tooth pattern of $M$. putorius, both in material from Poland ( $\mathrm{Ruprecht}$, 1965) and from Holland, and the cause of its occurrence must be sought for in disturbances in ontogenesis ( $\mathrm{G} \mathrm{l}$ a s, 1977).

Cases of fusing of teeth in $M$. putorius applied solely to the upper incisors, as in the case in the skunk (Gelder \& McLaughlin, 1961) and fox (Reinwaldt, 1962). It is not impossible that both fused and additional upper incisors in the common polecat may be cunsidered as homologous with the 7 and 8 upper incisor observed by B a teman (1970) in embryos and newborn young of laboratory ferrets. This author also considers that the character of additional upper incisors as being genetically established in ferrets may also characterize its hybrids with the common polecat. The more frequent occurrence of similar "anomalies " in man must, in $\mathrm{H}$ a ll's opinion (1940), be considered the result of hybridization between individuals from populations or races distinguished by differences in size of teeth and jaws.

Oligodonty in $M$. putorius is most often related to the extreme teeth (premolars and molars). According to $\mathrm{Hall}$ (1940) variation in tooth pattern in mammals is more often the result of oligodonty than polydonty. The first of these is the expression of a general trend towards specialization in the teeth of Carnivora and is usually manifested in reduction in the extreme teeth in the given row, Mustelidae not as yet being specialized in this respect to the same degree as Felidae and Canidae (Glas, 1977). The predominance of oligodonty in forming different variants of dentition in $M$. putorius from Poland is very distinct (Table 1), this being particularly clearly visible when polecats from Poland and Holland are compared (Table 2; Gla s, 1977). This leads to the assumption that the extreme teeth in a row may, in the case of the polecat, be broken early and consequently their alveoles may close over early (Röttcher, 1965). As in the weasel, all losses of premolars and canine teeth are explained by functional defects ( $N$ e u e ns c hwander \& Lüps, 1975). The increase of oligodonty in $M$. putorius with age, statistically documented, fully confirms the above assumption, just as does the analogical regularity occurring in the case of dentition in the short-tailed shrew (Choat e, 1968).

To conclude the above discussion it may be said that the tooth pattern of $M$. putorius from Poland is very stable. Typical dentition 
occurred in $91.7 \%$ of the males and $94.0 \%$ of the females. In the case of the 385 polecat skulls from Holland, however, the number of 34 teeth typical of the genus Mustela occurred in one specimen only (Glas, 1977). As in $M$. nivalis from Hesse, typical dentition was found in only $12 \%$ of the individuals ( $\mathrm{Neuenschwander} \& \mathrm{Lüps}, 1975$ ). The examples given provide clear proof of the wider occurrence of geographical variations in the tooth pattern of mammals, confirming earlier data given by $\mathrm{Heptner}$ (1968) on this subject. On the other hand it would simultaneously appear to point to the existence in small Mustelidae from Western Europe of tendencies to tooth pattern variation which are difficult to interpret. It is possible that this is the result and effect of combined action of different mutagenic factors, which in the case of Carnivora, which form the final link in the food chain, may be of exceptionally great significance.

It must be added here that a greater tendency for different deviations to occur in the number of teeth was found for common polecats from the Rzeszów population, which differed from the other Polish populations in respect of, inter alia, greater skull dimensions and its different proportions in the sex and age groups compared (B u chalczyk \& $\mathrm{Ruprecht}$, 1977). It is incidentally an interesting fact that this kind of similarity was also observed in the case of the short-tailed shrew, in which anomalies in dentition occurred more often in the subspecies of Blarina, distinguished by greater body measurements, than the remainder ( $\mathrm{C}$ h o a te, 1968).

\section{REFERENCES}

1. B a teman J. A., 1970: Supernumerary incisors in Mustelids. Mammal Rev., 1, 3: $81-86$.

2. Buchalczyk T. \& Ruprecht A. L., 1977: Skull variability of Mustela putorius L in na u s, 1758. Acta theriol., 22, 5: 87-120.

3. Choate J. R., 1968: Dental abnormalities in the short-tailed shrew, Blarina brevicauda. J. Mammal., 49, 2: 251-258.

4. Dolgov V. A. \& Ros s oli mo O. L., 1964: Slučaj anomalij v zubnoj sisteme volka, Canis lupus Linnaeus, 1758. Acta theriol., 8, 16: 237-244.

5. Fullagar P. J., Rogers T. H. \& Mansfield D., 1960: Supernumerary teeth in the badger. Proc. zool. Soc. Lond., 133, 3: 494.

6. Gelder R. G. Van \& McLaughlin C. A., 1961: An unusual incisor in Mephitis mephitis. J. Mammal., 42, 3: 422-423.

7. Gla s G. H., 1977: Numerical variation in the permanent dentition of the polecat, Mustela putorius (Linnaeus, 1758), from the Netherlands. Ztschr. Säugetierkde, 42, 4: 256-259.

8. Hall E. R., 1940: Supernumerary and missing teeth in wild mammals of the orders Insectivora and Carnivora, with some notes on disease. J. Dental Research, 19, 2: 103-143. 
9. Heptner V. G., 1968: Nekotorye teoretičeskie storony voprosa o podvide, podvidovyh priznakah i granicah podvidovyh arealov na primere geografičeskoj izmenčivosti dvuh palearktičeskih vidov mlekopitajuščih. Sb. trudov Zool. Muzeja MGU, 10: 3-36. Moskva.

10. Herá n̂ I., 1971: Some notes on dentition in Mustelidae. Vestn. Čs. spol. zool., 35, 3: $199-204$.

11. Mazák V., 1964: Anomalies of the second lower molars in Mustela nivalis nivalis Linnaeus, 1766 (Mammalia; Mustelidae). Nytt Mag. Zool., 12: 24-29.

12. Neuenschwander A. \& Lüps P., 1975: Zahnvariationen bei einer Mauswiesel-Population, Mustela nivalis Linné, 1766, aus Hessen. Säugetierkdl. Mitt., 23, 2: 85-93.

13. Opatrný E., 1973: Nĕkolik přikladů asymetrického chrupu u savců. Lynx, 14: $20-23$.

14. Re inwa ldt E., 1958: Über- und unterzählige Schneidezähne bei Musteliden. Säugetierkdl. Mitt., 6, 3: 97-100.

15. Reinwald E., 1962: Úber einige Anomalien im Gebiss des Rotfuchses, Vulpes vulpes vulpes Linné. Arkiv Zool., ser. 2, 15, 25: 371-375.

16. Röttcher D., 1965: Beiträge zur Alterbestimmung bei Nerz, Steinmarder und Iltis. Inaugural-Dissertation zur Erlangung des Doktorgrades bei der Veterinärmedizinischen Fakultät der Justus Liebig-Universität, 1-83. Giessen.

17. Ruprecht A., 1965: Supernumerary premolar in Mustela putorius Linn a e us, 1758. Acta theriol., 10, 17: 242.

Accepted, October 18, 1977.

Andrzej L. RUPRECHT

ZMIENNOSC UZĘBIENIA TCHORZA ZWYCZAJNEGO Z POLSKI

\section{Streszczenie}

Na serii czaszek Mustela putorius Linnaeus, 1758, zgromadzonych w okresie 1959-1970 z terenu Polski $(n=801)$ zbadano zakres zmienności formuły zębowej. Typowe dla rodzaju Mustela uzębienie liczące 34 zębów występowało u $91,7 \%$ samców i $94,0 \%$ samic. Oligodontia stwierdzona także w przypadku tchórza zwyczajnego z Polski jest zjawiskiem powszechnie występującym, jako ogólny trend specjalizacji uzębienia Carnivora. Przejawia się on najczęściej w redukcji zębów skrajnych w danym szeregu (Tabela 1). Stwierdzono ponadto, że oligodontia zwiększa się u $M$. putorius z wiekiem $(P<0.005)$. Przypadki polidontii dotyczyły u tchórza zwyczajnego przede wszystkim górnych siekaczy, rzadziej natomiast zębów trzonowych (Fig. 1). Pozostałe warianty uzębienia M. putorius dotyczyły zębów o koronach zrośniętych $\left(I^{1+2}\right)$ a także przedtrzonowców o nietypowej liczbie korzeni. Bardziej zmiennej formule zębowej tchórzy zwyczajnych z populacji rzeszowskiej towarzyszyły większe rozmiary czaszki. Porównanie liczby zębów $\mathrm{u}$ tchőrzy z Polski i Holandii wykazało u tych ostatnich bardzo silnie zaznaczoną skłonność do oligodontii (Tabela 2). 